\title{
Kreatywność w rozwiązywaniu problemów biznesowych
}

DOI: 10.47050/65591876.188-198

Sergiusz Sawin

W rozdziale przedstawiono sposób, w jaki duże organizacje i ich otoczenie zewnętrzne podchodzą do kwestii kreatywności oraz budują kompetencje w zakresie kreatywnego rozwiązywania problemów. Opisano typowe wyzwania stojące przed podmiotami biznesowymi chcącymi przekształcić się w prawdziwie kreatywne organizacje oraz narzędzia wykorzystywane na każdym etapie procesu, przez który przechodzi firma. Ponadto zaprezentowano studia przypadków opisujące faktyczne projekty realizowane przez wybrane duże organizacje noszące się z zamiarem wprowadzenia nowych kreatywnych rozwiązań. W ostatniej części wymieniono kilka technik wspierających kreatywne rozwiązywanie problemów.

\section{Słowa kluczowe:}

kreatywne rozwiązywanie problemów

innowacyjność

podważanie założeń

budowanie kreatywnych organizacji

kampanie innowacyjne

wymiana dobrych praktyk 


\section{Creativity in solving business problems}

DOI: 10.47050/65591876.188-198

Sergiusz Sawin

The article explains how creativity in big organisations is perceived by both internal and external stakeholders and how they build their skills and capabilities in the area of creative problem solving. The typical challenges faced by different business entities willing to turn into truly creative organisations are listed together with the tools used at different stages of their development. Author provides a couple of case studies of real business projects that were executed by big organisations willing to implement new creative solutions. Last part is dedicated to presentation of selected tools supporting creative problem solving.

\section{Keywords:}

creative problem solving

innovativeness

challenging assumptions

building creative organisations

innovation campaigns

sharing good practices 


\section{Kreatywność w biznesie - faktyczne działanie czy myślenie życzeniowe}

Jeżeliby spytać przedstawicieli dojrzałych organizacji o ustabilizowanych strukturach i pozycji rynkowej, czy kreatywność w biznesie jest istotnym elementem budowania pozycji rynkowej, z pewnością większość z nich odpowiedziałaby twierdząco. Firmy od lat inwestują w szkolenia kreatywności, programy proinnowacyjne, prowadzą spotkania typu "burze mózgów", szkolą wewnętrznych trenerów i wskazują w opisach stanowisk kreatywność jako pożądaną cechę każdego pracownika. W 2010 r. IBM przeprowadził bardzo szerokie badanie obejmujące swym zasięgiem ponad 1500 przedstawicieli najwyższego szczebla menedżerskiego. Podczas badania pytano o to, jakie cechy przywódcze będą najistotniejsze w ciągu najbliższych pięciu lat. Ponad $60 \%$ badanych osób wskazało kreatywność jako najważniejszą cechę przyszłego lidera (IBM 2010).

Z drugiej strony, na podstawie mojej wieloletniej praktyki korporacyjnej, a także doradczej w projektach innowacyjnych dla dużych korporacji, mogę stwierdzić, że w bardzo niewielu organizacjach pozytywny stosunek do działań wspierających kreatywność przekłada się na konkretne zmiany w sposobie myślenia kierownictwa firmy, tak aby zmieniać organizację w sposób systemowy i dogłębny.

Z tezą tą zgadza się także większość konsumentów i klientów dużych międzynarodowych firm. Według badania przeprowadzonego przez magazyn „TRUE" w 2016 r. prawie $72 \%$ respondentów stwierdziło, że większości korporacji nie można uznać za kreatywne firmy (Corporations, Creativity and Consumers 2016).

Dzieje się tak z kliku powodów. Po pierwsze, celem dużych organizacji, a w szczególności korporacji, jest długofalowy stabilny wzrost zysku. Aby ów cel osiągnąć, zarządy i menedżerowie wyższego szczebla skupiają się przede wszystkim na prowadzeniu działań, które zminimalizują potencjalne zaburzenia tego wzrostu w krótkim i średnim terminie. Każde niesprawdzone, niestandardowe działanie, a do takich niewątpliwie należą działania kreatywne, stanowi więc potencjalne ryzyko destabilizacji.

Drugim istotnym czynnikiem, który może blokować kreatywność organizacji, jest kultura biznesowa czy ogół przyjętych wzorców zachowań i postaw pracowników w miejscu pracy. Na kulturę biznesową składają się także takie elementy jak: otwartość na zmiany, zdolność 
do podejmowania ryzyka, sposób budowania relacji w ramach struktury organizacyjnej, zakres autonomii w podejmowaniu decyzji, przywiązanie do sprawdzonych sposobów postępowania. Wszystkie wymienione obszary kultury mogą mieć negatywny wpływ na promowanie niestandardowych postaw, ponieważ z założenia oczekuje się, że nowo przyjęty pracownik dostosuje się do utartych schematów postępowania, a nie odwrotnie. Jedynie w przypadku zmian na najwyższych stanowiskach w firmie, czyli prezesa i zarządu, możemy upatrywać szansy na głębsze zmiany kultury organizacyjnej.

Po trzecie, sam sposób rekrutacji pracowników zachęca do utrzymania status quo. Na każde stanowisko $w$ firmie szuka się pracowników o określonym, jasno zdefiniowanym profilu zgodnym z oczekiwaniami. Podczas rekrutacji promuje się osoby z dużym doświadczeniem w branży, a więc takie, które mogą przynieść ze sobą do firmy wiedzę o dobrych praktykach wyniesionych z podobnych organizacji. Nie spotkałem się z sytuacją, żeby na stanowisko np. dyrektora marketingu szukano osoby, która nigdy w marketingu nie pracowała, a przykładowo jest wziętym artystą. W ten sposób utrwalamy aktualne schematy postępowania, co prawda, wzbogacając firmę o trochę doświadczeń branżowych, ale cały czas poruszając się w bezpiecznym środowisku.

Po czwarte wreszcie, sama domena czystej kreatywności jest w dużych organizacjach zarezerwowana dla partnerów i dostawców firmy, w tym przede wszystkim agencji kreatywnych, agencji eventowych, domów mediowych, zewnętrznych trenerów i konsultantów. To od pracowników tych podmiotów oczekuje się kreatywności, niestandardowego spojrzenia, świeżych pomysłów, łamania schematów i inspiracji, która i tak zostanie potem zamknięta w bezpieczne ramy organizacji. W rezultacie pracownik firmy nie musi być kreatywny, ponieważ ma od tego ludzi, którym za to płaci.

Czy zatem do rozwiązywania problemów biznesowych potrzebna jest kreatywność? Czy nie wystarczy sięgnąć do sprawdzonych wzorów z własnej lub pokrewnych branż i, nie podejmując specjalnie ryzyka, zaadaptować je do bieżącego kontekstu?

Dawniej być może to wystarczało. Dziś, w czasach rewolucji cyfrowej, opieranie się wyłącznie na wzorcach z przeszłości może być śmiertelną pułapką, choć w różnych branżach sytuacja może wyglądać zupełnie inaczej. 


\section{Gotowość organizacji do kreatywnego rozwiazywania problemów}

Organizacje przechodzą kilka stadiów rozwoju. Wspomniana wcześniej zdolność absorpcji dobrych praktyk z wewnątrz lub zewnątrz organizacji jest pierwszym krokiem w stronę budowania prawdziwie kreatywnej organizacji zdolnej do skutecznego wdrażania niestandardowych pomysłów. Jest to jednak dopiero początek długiej drogi, którą duża firma musi przejść.

STUDIUM PRZYPADKU: ZBIERANIE DOBRYCH PRAKTYK

Zarząd dużej sieci restauracji działającej na zasadach franczyzy podczas corocznego zjazdu franczyzobiorców postanowił zorganizować warsztaty dobrych praktyk, podczas których kilkanaście zespołów składających się głównie z właścicieli poszczególnych restauracji zostało poproszonych o opisanie dobrych praktyk przynoszących wymierne korzyści w ich placówkach. Zespoły podzielono według kilku głównych obszarów tematycznych typu: zarządzanie kosztami, motywowanie pracowników, obsługa klienta itp.

Efektem warsztatów miało być stworzenie tzw. księgi dobrych praktyk, czyli podręcznika franczyzobiorcy, z opisami wszystkich działań usprawniających pracę restauracji. W ramach warsztatów przeprowadzono także głosowanie i wybierano najlepsze „dobre praktyki", a ich autorzy otrzymywali nagrody specjalne ufundowane przez zarząd firmy. Główne kryteria oceny to: prostota wdrożenia i wymierny efekt. Jedną z dobrych praktyk wyróżnionych tego dnia w kategorii: „zarządzanie kosztami" była praktyka codziennego odkurzania wentylatora po zamknięciu restauracji. Jak się okazało, pył z mąki unoszący się podczas wyrabiania ciasta do pizzy zatykał wentylator tak skutecznie, że koszt energii pobranej do jego pracy znacznie wzrastał. Odkurzanie wentylatora pozwoliło każdego dnia zaoszczędzić kilkanaście procent na kosztach energii elektrycznej.

\section{Tabela 1. Ewolucja kreatywnych organizacji}

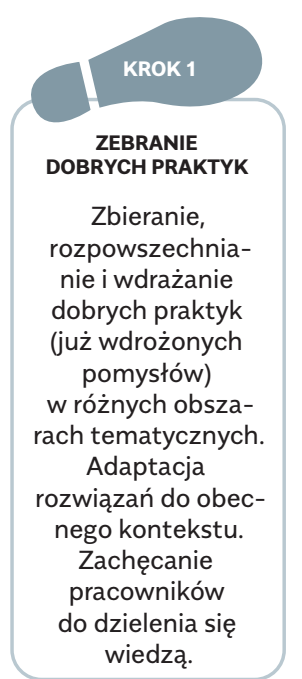

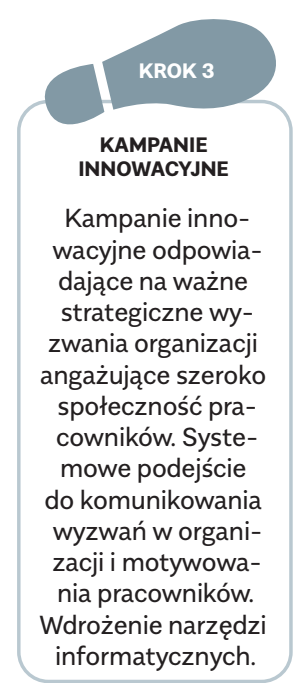

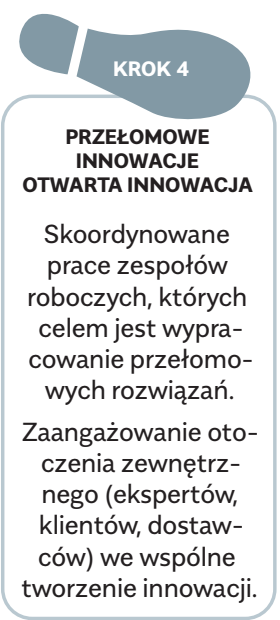

Źródło: opracowanie własne. 
Pierwsze dwa etapy mają na celu przede wszystkim budowanie otwartości w organizacji, promowanie dzielenia się wiedzą i swoimi doświadczeniami. Problemy biznesowe mają tutaj znaczenie drugorzędne i mogą raczej stanowić pewnego rodzaju inspirację. Nie oczekuje się od pracowników przyniesienia kreatywnego przełomowego rozwiązania, a raczej czegoś, co jest bezpieczne, sprawdzone i co łatwo wdrożyć.

Dopiero dzięki pozytywnym doświadczeniom i lekcjom wyciągniętym z działań podjętych na tych dwóch pierwszych etapach większość organizacji zaczyna rozważać wdrożenie systemowego podejścia do rozwiązywania problemów organizacji. Najczęściej wybieraną ścieżką są kampanie innowacyjne, a więc zbudowanie usystematyzowanego procesu zbierania pomysłów pracowników, odpowiadających na określone wyzwania biznesowe. Kampanie mogą obejmować całą społeczność pracowników firmy lub być ograniczone do ściśle określonej grupy, np. pracowników placówek banku, przedstawicieli handlowych lub działu obsługi klienta. Aby kampanie były skuteczne, muszą opierać się na kilku podstawowych założeniach.

\section{STUDIUM PRZYPADKU: KAMPANIE INNOWACYJNE}

W 2005 r. Telekomunikacja Polska S.A. wdrożyła program „Innovate TP!”. Jednym z jego obszarów było budowanie klimatu dla innowacyjności i włączanie pracowników w kreatywne rozwiązywanie problemów. Zdecydowano się przetestować podejście kampanijne. Grupa menedżerów wyższego szczebla została poproszona o przysłanie propozycji wyzwań istotnych dla organizacji, które mogły posłużyć za tematy pierwszych kampanii. Zapoznając się z zebranymi propozycjami, komitet sterujący zdecydował się na wybór następującego tematu: „W jaki sposób zmniejszyć wskaźnik churnu i skłonić klientów do pozostania z nami”. Churn to wskaźnik odejścia klientów, a więc bardzo istotny czynnik sukcesu działania każdej organizacji. W przypadku Telekomunikacji Polskiej w tym okresie, gdy wielu klientów rezygnowało z telefonów stacjonarnych, wysoki wskaźnik churnu był istotnym problemem.

Kampania trwała trzy tygodnie, zebrano kilkadziesiąt pomysłów oraz kilkaset komentarzy i uzupełnień do nich. Wiele z nich było naprawdę bardzo kreatywnych. Zwyciężył pomysł, który dzisiaj nikogo nie dziwi, ale w tamtym czasie był w jakimś stopniu przełomowy. Zdaniem pomysłodawcy najlepszym sposobem na redukcję churnu jest kontakt z klientem mniej więcej 1-2 miesiące przed upływem terminu zakończenia umowy w celu jej odnowienia. Pomysł został oczywiście w szybkim czasie wdrożony, co przełożyło się na znaczną redukcję churnu i w krótkim czasie stało się standardem nie tylko w branży telekomunikacyjnej.

Założenia kampanii innowacyjnych:

$\rightarrow$ Każda kampania ma jasno zdefiniowane wyzwanie biznesowe posiadające właściciela, zwykle osobę z zarządu firmy lub menedżerów wyższego szczebla. 
$\rightarrow$ Pomysły należy zgłaszać przez odpowiednio przygotowany formularz dopasowany każdorazowo do wyzwania i oczekiwań ekspertów i sponsora. Bardziej złożony formularz ogranicza liczbę pomysłów, ale powoduje, że zgłaszane pomysły są lepiej dopracowane.

$\rightarrow$ Kampania trwa przez ściśle określony czas, po którym wyznaczone grono ekspertów ocenia zgłoszone pomysły.

$\rightarrow$ Zwykle pomysły zgłaszane są za pomocą narzędzia informatycznego, które umożliwia nie tylko wpisywanie pomysłów, ale także ich komentowanie i sprawną ocenę przez ekspertów, a także monitorowanie aktywności pracowników.

$\rightarrow$ Dla każdej kampanii tworzy się system motywacyjny. W bardziej zaawansowanych kampaniach pracownicy otrzymują nagrody nie tylko za najlepsze pomysły, ale także za aktywność w kampanii i wkład w rozwój pomysłów zgłoszonych przez innych.

Firmy mające już za sobą kilka lub kilkanaście kampanii innowacyjnych stopniowo otwierają się na współpracę z otoczeniem zewnętrznym. Do kampanii zapraszani są zaufani partnerzy firmy (dostawcy, odbiorcy, kluczowi klienci). Ich wkładem są często pomysły niestandardowe, czerpiące $z$ doświadczeń ze współpracy z innymi partnerami. Przy specyficznych wyzwaniach pomóc może także konkretna wiedza branżowa. Może się także okazać, że podmioty partnerskie mają w swoim harmonogramie projektów badawczo-rozwojowych rozwiązania częściowo lub w pełni odpowiadające na wyzwanie zgłoszone podczas kampanii. Praca nad problemem klienta może więc skutkować przyspieszeniem działań w określonym obszarze, aby szybciej odpowiedzieć na zgłoszoną potrzebę. Praca z klientami zewnętrznymi może odbywać się na zasadach podobnych do tych w kampaniach innowacyjnych lub też $w$ formie warsztatów kreatywnych prowadzonych przez firmę lub wynajętych trenerów zewnętrznych.

Warsztaty takie często stanowią początek szerszej współpracy w formule tzw. Rady Klienta (Customer Advisory Boards), polegającej na organizowaniu cyklu regularnych spotkań poświęconych różnym tematom dotyczącym oferty i rozwiązywania bieżących problemów pojawiających się w toku współpracy.

$\mathrm{Na}$ tym etapie dojrzałości organizacji zwykle jeszcze nie ma jednolitej strategii otwierania się na otoczenie zewnętrzne. To, jaki charakter 
przybierze współpraca z partnerami biznesowymi, a w szczególności z bardzo popularnymi ostatnio start-upami, zależy w dużej mierze od tego, jaka część organizacji tę współpracę inicjuje i jakie cele chce przy tym zrealizować.

Tabela 2. Główne działy w organizacji i ich cele oraz motywacje

\begin{tabular}{|c|c|c|c|c|}
\hline DZIAŁ HR & MARKETING \& PR & $\begin{array}{l}\text { LOGISTYKA, } \\
\text { SPRZEDAŻ, } \\
\text { MARKETING, } \\
\text { PRODUKCJA }\end{array}$ & $\begin{array}{l}\text { DZIAE STRATEGII, } \\
\text { INNOWACJI, CVC } \\
\text { (CORPORATE } \\
\text { VENTURE CAPITAL) }\end{array}$ & DZIAŁ R\&D \\
\hline $\begin{array}{l}\text { budowanie kul- } \\
\text { tury wspierającej } \\
\text { transformację } \\
\text { cyfrową biznesu, } \\
\text { budowanie start- } \\
\text {-up mindset, za- } \\
\text { rządzanie zmianą } \\
\text { w organizacji }\end{array}$ & $\begin{array}{l}\text { wzmocnienie } \\
\text { wizerunku firmy } \\
\text { jako firmy kre- } \\
\text { atywnej, otwartej } \\
\text { na start-upy, } \\
\text { angażującej się } \\
\text { we współpracę } \\
\text { z ekosystemem } \\
\text { start-upowym, } \\
\text { budowanie } \\
\text { wizerunku wśród } \\
\text { potencjalnych } \\
\text { przyszłych pra- } \\
\text { cowników firmy }\end{array}$ & $\begin{array}{l}\text { poszukiwanie } \\
\text { rozwiązań bieżą- } \\
\text { cych problemów }\end{array}$ & $\begin{array}{l}\text { poszukiwanie } \\
\text { pomysłów na } \\
\text { nowe produkty } \\
\text { i usługi poza } \\
\text { podstawową } \\
\text { działalnością }\end{array}$ & $\begin{array}{l}\text { poszukiwanie } \\
\text { technologii we } \\
\text { wczesnej fazie } \\
\text { rozwoju w celu } \\
\text { zwiększenia } \\
\text { efektywno- } \\
\text { ści produkcji, } \\
\text { zmniejszenia } \\
\text { kosztów, wy- } \\
\text { eliminowania } \\
\text { niepożądanych } \\
\text { skutków, rozwój } \\
\text { oferty }\end{array}$ \\
\hline
\end{tabular}

Źródło: Sawin 2018.

STUDIUM PRZYPADKU: KREATYWNE WARSZTATY Z PARTNERAMI BIZNESOWYMI

W 2013 r. firma Żywiec Zdrój pracowała nad koncepcją nowego produktu przeznaczonego dla młodzieży. Do tej pory większość podobnych projektów realizowano w całości wewnętrznie. W skład zespołu projektowego wchodzili pracownicy działów R\&D, marketingu i strategii. Klasyczne podejście polegało na przygotowaniu briefu przez dział strategii, w którym wstępnie określono cele biznesowe dla nowego produktu. Następnie dział marketingu na podstawie szerokich badań rynkowych definiował rodzaj produktu oraz segment, do którego ma być kierowany. Tak przygotowane zlecenie trafiało do działu R\&D, gdzie przeprowadzano analizy techniczne, kontaktowano się z producentami opakowań i środków spożywczych i przygotowywano koncepcję produktu do dalszych badań przez marketing. Tym razem postanowiono zmienić podejście i od początku zaangażować potencjalnych dostawców produktu w proces wymyślania koncepcji. Opracowano koncepcję intensywnego jednodniowego warsztatu kreatywnego, w którym mieli uczestniczyć pracownicy kluczowych działów firmy oraz przedstawiciele pięciu niekonkurujących ze sobą dostawców różnych komponentów do produkcji końcowego produktu, m.in. dostawca opakowań PET, producenci zakrętek i etykiet. Każdego z nich poproszono o przyjście na warsztat z koncepcjami innowacyjnych rozwiązań z ich obszaru, odpowiadających na wyzwania, z którymi mierzył się klient. Dzięki temu podczas warsztatu mieszane zespoły pracowników Żywiec Zdrój i kilku dostawców, pracując nad wstępnymi koncepcjami cząstkowymi, mogły w ciągu jednego dnia przygotować spójne pomysły rozwiązań odpowiadających na strategiczną potrzebę firmy i zawierających wszystkie niezbędne składowe docelowego produktu. 
Organizacje, które mają już za sobą wiele doświadczeń związanych z pobudzaniem zarówno wewnętrznej, jak i zewnętrznej kreatywności w celu rozwiązywania bieżących problemów biznesowych, zaczynają wdrażać narzędzia i procesy wspierające poszukiwanie nowych modeli biznesowych i produktów wykraczających poza standardowo oferowane kategorie produktowe. Tego typu działania wymagają przebudowy organizacji, ponieważ radykalnych innowacji nie da się realizować wyłącznie za pomocą dotychczasowych metod i środków. Nie sprawdza się tradycyjne podejście typu waterfall oraz stosowany standardowo liniowy proces stage-gate, w którym zakłada się, że kolejne etapy tworzenia rozwiązania następują w ściśle określonej kolejności na podstawie założeń projektu zdefiniowanych już na samym początku. Są to podejścia z natury przygotowane do tworzenia innowacji inkrementalnych opartych na weryfikacji sprawdzonych wcześniej założeń, bazujące na dotychczasowych kompetencjach i udokumentowanej wiedzy rynkowej. Przygotowanie do tworzenia radykalnych innowacji wymaga więc powołania osobnych jednostek biznesowych o odrębnie zdefiniowanych celach, nowych kompetencjach i wiedzy na temat metod i narzędzi stosowanych przez młode spółki technologiczne i start-upy. Wiele dojrzałych przedsiębiorstw przekonało się boleśnie, jak trudno stworzyć radykalnie nowy biznes, bazując wyłącznie na dotychczasowym zespole z wszystkimi jego ograniczeniami i założeniami, które z czasem stają się dogmatami skutecznie paraliżującymi jakiekolwiek wysiłki zmierzające do ich podważenia. A przecież gdyby prześledzić historie sukcesów tzw. unicornów, a więc firm, które w bardzo krótkim czasie podbiły światowy rynek, osiągając ogromną wartość rynkową, bardzo łatwo można dojść do wniosku, że ich podstawową motywacją było podważanie założeń przyjętych wcześniej w branży, którą postanowili podbić. 
STUDIUM PRZYPADKU: PODWAŻANIE ZAŁOŻEŃ W BRANŻY OŚWIETLENIOWEJ

Jeden z głównych producentów oświetlenia od kilku lat planował odświeżenie swojej oferty oświetlenia sufitowego dla biur. W przeszłości firma słynęła z innowacyjnych rozwiązań, wiele razy wprowadzając jako pierwsza na rynek nowe produkty, m.in. energooszczędne neony, nowe barwy i niestandardowe obudowy. W ostatnim czasie konkurencja się zaostrzyła i mimo że standardowe linie produktowe sprzedawały się bardzo dobrze, zarząd miał poczucie, że brakuje im świeżych pomysłów, które na nowo zdefiniowałyby ich pozycję lidera w branży. Organizowano warsztaty kreatywne, wprowadzono narzędzia do zarządzania pomysłami, opracowano system motywacyjny dla innowatorów, ale wciąż brakowało naprawdę kreatywnych pomysłów. W końcu zdecydowano się zatrudnić firmę zewnętrzną, która mogłaby spojrzeć z dystansem na ofertę firmy i ocenić jej działalność z nowej perspektywy.

$Z$ pomocą zewnętrznych moderatorów zdecydowano się kolejny raz przeprowadzić warsztaty kreatywne, ale tym razem ich formuła była odmienna. Trenerzy poprosili zebrany multidyscyplinarny zespół o wypisanie wszystkich głównych założeń dla obecnych produktów. Chodziło o najbardziej podstawowe założenia, np. takie, że lampa ma świecić. Wkrótce stworzono listę około dwudziestu założeń, w tym takie jak: oświetlenie sufitowe świeci tak samo przez cały dzień, oświetlenie sufitowe znajduje się zawsze w tym samym miejscu, jedyną funkcją lamp biurowych jest oświetlenie miejsca pracy oraz lampa sufitowa, kiedy się zepsuje, przestaje świecić. Następnie poproszono kilka zespołów o wybór założeń, które można byłoby podważyć i na podstawie zmienionych założeń stworzyć kreatywne koncepcje nowych rozwiązań. Okazało się, że dopiero przy zastosowaniu tak niestandardowych metod, zaczęły pojawiać się prawdziwie przełomowe pomysły, m.in. oświetlenie podążające za człowiekiem, lampy zmieniające natężenie oświetlenia w zależności od pory dnia i roku, jarzeniówki informujące, że za kilka dni przestaną świecić.

\section{Znajdź swoje techniki kreatywne}

Niezależnie od tego, na którym etapie znajduje się organizacja i jak wiele ma za sobą doświadczeń w stymulowaniu kreatywności, nieprawdą jest stwierdzenie, że istnieje jedna sprawdzona technika, która pomogłaby rozwiązać każdy problem. Najlepiej próbować wielu i nie zrażać się, gdy nie przynoszą one pożądanych rezultatów. Może się zdarzyć, że w danych okolicznościach i określonym składzie osobowym grupa nie jest w stanie znaleźć żadnego trafionego pomysłu. Nie powinno to być powodem do rozpaczy, ponieważ w pracy kreatywnej nigdy nie da się zagwarantować sukcesu. $Z$ drugiej strony nawet najbardziej fantastyczne pomysły mogą być niemożliwe do zrealizowania. Brytyjska firma WhatIf!, odpowiednik amerykańskiego Ideo, proponuje kilka narzędzi, które sprawdzają się w codziennym rozwiązywaniu problemów biznesowych swoich klientów. Zachęca do ich stosowania w każdej sytuacji, w której brakuje oczywistej odpowiedzi na powstały problem lub odpowiedź ta wydaje się niewystarczająca. Są to tak zwane 4-R (WhatIF! 2002): 
Re-expression - zdefiniuj problem, przed którym stoisz, w sposób inny niż do tej pory (np. słowami kogoś, kto nie jest powiązany z twoją organizacją, odbiorcy, użytkownika końcowego), użyj alternatywnych słów, których nie używasz na co dzień, lub innych zmysłów.

Related worlds - załóż, że z danym problemem ktoś już się kiedyś mierzył, być może w innych branżach i kontekstach, spójrz na biznesy bardzo odmienne od twojego i zastanów się, jak ich przedstawiciele do tego problemu podeszli w przeszłości lub jak mogliby podejść w przyszłości. Znajdź eksperta spoza firmy i otoczenia konkurencyjnego, który mógłby coś wnieść w zrozumienie problemu i znalezienie rozwiązania, i zapytaj go, jakie są jego pomysły.

Revolution - zmień reguły gry i sprowokuj zespół do myślenia. Podważ obecne założenia i zasady, świadomie odwróć reguły i zastanów się, jakie pomysły można byłoby stworzyć, gdyby obowiązywały zupełnie inne zasady (zamiast moczyć, wysusz, substancję stałą zmień w ciekłą, miłą obsługę zmień w stanowczą i asertywną itp.).

Random links - kreatywność powstaje w efekcie zupełnie niestandardowych połączeń różnych skojarzeń i elementów. To dlatego nasze sny wydają się nam tak kreatywne. Daj sobie czas na znalezienie zupełnie dziwacznych połączeń z losowo wybranych słów i zobacz, dokąd cię to zaprowadzi.

\section{Podsumowanie}

Mimo że kreatywny pomysł często rodzi się z przypadku, organizacja, która chce być trwale kreatywna, nie powinna niczego zostawiać przypadkowi. Aby skutecznie rozwiązywać problemy biznesowe, firma musi, po pierwsze, mieć głębokie przekonanie, że w kreatywność warto inwestować w sposób systemowy: budując odpowiednie struktury i procesy, ale także inwestując w odpowiednich ludzi i narzędzia wspierające. Po drugie, zarząd firmy powinien uświadomić sobie, że bycie kreatywnym liderem to długi proces składający się z kilku etapów, począwszy od zbierania dobrych praktyk i wdrażania drobnych usprawnień, aż po złożone projekty tworzenia nowych modeli biznesowych. Kreatywne organizacje są tworzone przez kreatywnych, zmotywowanych ludzi i dlatego tak ważna jest zmiana kultury organizacyjnej, której nie da się przeprowadzić z dnia na dzień. 